\title{
Are changes in the pharmacokinetic (PK) and pharmacodynamic (PD) properties of antipsychotics able to improve efficacy and
}

\author{
safety? \\ Luca Pani ${ }^{1,2}$
}

\author{
Address: ${ }^{1}$ National Research Council of Italy and ${ }^{2}$ PharmaNess Scarl, Scientific \& Technological Park of Sardinia Cagliari, Italy \\ from International Society on Brain and Behaviour: 3rd International Congress on Brain and Behaviour \\ Thessaloniki, Greece. 28 November - 2 December 2007 \\ Published: 17 April 2008 \\ Annals of General Psychiatry 2008, 7(SuppI I):S77 doi:10.II86/I744-859X-7-SI-S77
}

This abstract is available from: http://www.annals-general-psychiatry.com/content/7/SI/S77

(c) 2008 Pani; licensee BioMed Central Ltd.

Although atypical antipsychotics have provided clinical advantages over conventional medications, data from trials such as CATIE [1] have highlighted that there is still a need for improved medications to support continued adherence and optimal clinical outcomes. In particular, it would be of benefit to minimize side effects such as extrapyramidal symptoms (EPS) and weight gain. One approach to optimize antipsychotic activity is to modulate the pharmacokinetic profile and thus deliver improved pharmacodynamic effects. Oral formulations of antipsychotics are generally characterized by a relatively rapid rise and fall in plasma concentrations with levels above and below threshold levels being associated with an increased risk of side effects and reduced antipsychotic efficacy, respectively [2]. Achieving steady plasma levels at which the drug achieves maximum symptom control but below levels at which adverse events occur therefore remains the ideal profile. For atypical antipsychotics, efficacy begins at approximately $60 \%$ occupancy of the $\mathrm{D} 2$ receptor, and occupancy above $80 \%$ can lead to EPS [2-4]. Approaches to reduce the peak-to-trough fluctuations compared with immediate-release oral agents include the use of long-acting injectable agents which have smoother plasma concentration-time profiles [2,5]. For those patients who prefer oral agents, alongside the choice of agents such as olanzapine, quetiapine, ziprasidone and risperidone, there is the option of using paliperidone ER which uses oral osmotic pump (OROS) extended-release technology [6]. This provides a continual release of medication leading to minimal peaks and troughs in plasma concentrations over a 24-hour period. A sustained release formulation of quetiapine is also currently being assessed in clinical trials [7].

\section{References}

I. Lieberman JA, Stroup TS, McEvoy JP, Swartz MS, Rosenheck RA, Perkins DO, Keefe RS, Davis SM, Davis CE, Lebowitz BD, Severe J, Hsiao JK: Clinical Antipsychotic Trials of Intervention Effectiveness (CATIE) Investigators. Effectiveness of antipsychotic drugs in patients with chronic schizophrenia. N Engl J Med 2005, 353:1209-1223.

2. Medori R, Mannaert E, Gründer G: Plasma antipsychotic concentration and receptor occupany, with special focus on risperidone long-acting injectable. Eur Neuropsychopharmacol 2006, 16:233-240.

3. Kapur S, Zipursky R, Jones C, Remington G, Houle S: Relationship between dopamine $D(2)$ occupancy, clinical response, and side effects: a double-blind PET study of first-episode schizophrenia. Am J Psychiatr 2000, 157:5।4-520.

4. Pani L, Pira L, Marchese G: Antipsychotic efficacy: relationship to optimal D2-receptor occupancy. Eur Psychiatry 2007, 22:267-275.

5. Mamo D, et al.: Neuropsychopharmacology. 2004 in press.

6. Conley R, Gupta SK, Sathyan G: Clinical spectrum of the osmotic-controlled release oral delivery system (OROS), an advanced oral delivery form. Curr Med Res Opin 2006, 22:1879-1892.

7. Kahn RS, Schulz SC, Palazov VD, Reyes EB, Brecher M, Svensson O, Andersson HM, Meulien D: Study I 32 Investigators. Efficacy and tolerability of once-daily extended release quetiapine fumarate in acute schizophrenia: a randomized, double-blind, placebo-controlled study. J Clin Psychiatry 2007, 68:832-842. 